\title{
Dampak Pandemi Covid-19 terhadap Kinerja Keuangan Perusahaan Sektor Jasa di BEI
}

\section{Covid-19 Pandemic Impact towards the Financial Performance of Companies on Service Sector in BEI}

\author{
Maria J. F Esomar'1, Restia Chritianty ${ }^{1}$ \\ 1)Jurusan Manajemen, Fakultas Ekonomi dan Bisnis, Universitas Pattimura, Ambon, Indonesia \\ *Coresponding Email: dyahesomar@gmail.com
}

\begin{abstract}
Abstrak
Pandemi Covid-19 telah menyebabkan banyak hotel, restoran, dan kegiatan pariwisata ditutup sementara. Hal tersebut berdampak pada kinerja keuangan perusahaan yang bergerak di sub-sektor ini. Penelitian ini bertujuan untuk menganalisis pengaruh Covid-19 terhadap kinerja keuangan perusahaan yang bergerak di sub-sektor perhotelan, restoran dan pariwisata. Kinerja keuangan diukur dengan menggunakan beberapa rasio, yaitu rasio likuiditas, rasio solvabilitas, rasio profitabilitas dan rasio pasar. Jenis penelitian yang dilakukan adalah penelitian kuantitaitf deskriptif. Populasi dalam penelitian ini adalah 35 seluruh perusahaan sub-sektor perhotelan, restoran dan pariwisata yang terdaftar di Bursa Efek Indonesia periode 2019-2020. Sampel dikumpulkan 30 perusahaan dengan menggunakan metode purposive sampling. Pengujian hipotesis dilakukan dengan menggunakan paired sample t-test. Hasil empiris menunjukkan bahwa, pada rasio likuiditas dan rasio pasar tidak terdapat perbedaan yang signifikan di antara periode sebelum dan periode sesudah kasus Covid-19 pertama kali diumumkan di Indonesia. Sedangkan, pada rasio solvabilitas dan rasio profitabilitas, terdapat perbedaan yang signifikan di antara kedua periode tersebut.
\end{abstract}

Kata Kunci: Pandemi Covid-19, Kinerja Keuangan, Analisa Rasio.

\begin{abstract}
The Covid-19 pandemic has caused many hotels, restaurants and tourism activities to be temporarily closed. It has an impact on the financial performance towards the companies engaged in this sub-sector. The objective of this study is to analyze the impact of Covid 19 towards the financial performance of companies engaged in the subsector of hotel, restaurant and tourism. Financial performance is measured using several ratios, namely liquidity ratios, solvability ratios, profitability ratios and market ratio. The ype of research is descriptive quantitave. The population in this study is 35 all companies in the sub-sector of hotel, restaurant and tourism listed on the Indonesia Stock Exchange in 2019-2020 period. Samples are collected from 30 companies using purposive sampling method. Hypothesis testing is conducted using the Paired Sample t-Test. The empirical results show that, in the liquidity ratio, and market ratio there is no significant difference between the periods of before and after the first recorded Covid-19 case in Indonesia. Meanwhile, in the solvability ratio and profitability ratio, there are significant differences between the two periods.
\end{abstract}

Keywords: Covid-19 Pandemic, Financial Performance, Ratio Analysis.

How to Cite: Esomar, M.J.F., \& Chritianty, R. (2021). Dampak Pandemi Covid-19 terhadap Kinerja Keuangan Perusahaan Sektor Jasa di BEI, JKBM (Jurnal Konsep Bisnis dan Manajemen). 7 (2): 227-233 
Esomar, M.J.F., \& Chritianty, R. (2021). Dampak Pandemi Covid-19 terhadap Kinerja Keuangan Perusahaan ...

\section{PENDAHULUAN}

Pariwisata merupakan salah satu sektor yang efektif meningkatkan penerimaan devisa negara. Tahun 2018, pariwisata di Indonesia mencatat pertumbuhan tertinggi dan berada pada peringkat 9 dunia berdasarkan data dari The World Travel \& Tourism Council (WTTC). (Rahma, 2020). Penerimaan Domestik Bruto dari sektor pariwisata rata-rata meningkat selama 4 tahun terakhir sebesar $4.7 \%$, sektor pariwisata selama 4 tahun terakhir juga mampu menyerap tenaga kerja sebesar 11.98 juta.

Awal tahun 2020, sektor ini mengalami perlambatan akibat dari mewabahnya virus Covid-19. Sektor pariwisata merupakan salah satu sektor yang terkena dampak pandemi Covid 19, (Sugihamretha, 2020). Kebijakan pelarangan mobilitas antar wilayah termasuk aktivitas wisata mengakibatkan jumlah kunjungan ke tempattempat wisata mengalami penurunan. Destinasi wisata di Indonesia yang terkenal antara lain Bali, Lombok dan Yogyakarta mengalami penurunan wisatawan yang cukup signifikan. (Utami \& Kafabih, 2020). Imigrasi Bali mencatat pada Februari 2020 jumlah wisatawan mengalami penurunan
33\% yang diakibatkan antara lain karena menurunnya kunjungan dari wisatawan China yang mana wisatawan China merupakan penyumbang terbesar (Sugihamretha, 2020)

Jumlah hunian Hotel di Bali menurun 70\% sejak terjadinya pandemi Covid-19 1.266 hotel di 31 propinsi di Indonesia ditutup per April 2020. (Siswantoro, 2020). Kondisi ini turut mempengaruhi pemerintah untuk membuat kebijakan yang mendorongan peningkatan kinerja industri selama masa pandemi ini.

Sebelum pandemi Covid-19, sektor pariwisata mencatat pertumbuhan laba, namun sesudah terjadinya pandemi Covid-19 sektor ini mengalami penurunan kinerja. Kunjungan wisatawan menurun drastis karena berkurangnya penerbangan internasional, wisatawan lokal juga mengalami penurunan karena adanya kebijakan social and physical distancing (LPEM-FEB-UI, 2020). Usaha perhotelan, restoran dan pariwisata mengalami penurunan tajam.

Tabel 1 Laba Usaha TW III tahun 2019 dan tahun 2020 Perusahaan sub sektor Hotel, Restoran dan Pariwisata yang terdaftar di Bursa Efek Indonesia (BEI)

\begin{tabular}{|c|c|c|}
\hline Kode & Labaa TW III 2019 & Laba TW III 2020 \\
\hline BAYU & -448.936 .569 & -10.255 .684 .673 \\
\hline BUVA & -46.256 .312 .305 & 97.858 .408 .247 \\
\hline CLAY & -21.987 .463 .603 & 50.161 .361 .020 \\
\hline DFAM & 4.394 .672 .629 & -8.569 .084 .748 \\
\hline DUCK & 129.210 .519 .100 & 20.587 .347 .950 \\
\hline EAST & 2.396 .112 .518 & 605.330 .297 \\
\hline FAST & 124.445 .386 & -282.256 .364 \\
\hline FITT & -4.575 .798 .184 & -6.800 .258 .751 \\
\hline HOTL & 2.671 .538 .474 & -33.529 .566 .972 \\
\hline HOME & -24.333 .282 .856 & -12.280 .191 .585 \\
\hline HRME & -3.772 .314 .959 & -23.883 .837 .246 \\
\hline ICON & 17.244 .355 .824 & 2.172 .481 .800 \\
\hline INPP & 1.938.470.514.259 & 73.910 .838 .717 \\
\hline
\end{tabular}




\begin{tabular}{lcr}
\hline \multicolumn{1}{c}{ Kode } & Labaa TW III 2019 & Laba TW III 2020 \\
\hline JGLE & -86.077 .995 .686 & -64.802 .183 .891 \\
\hline JIHD & 95.330 .871 & -128.911 .988 \\
\hline JSPT & 77.172 .772 & -294.900 .703 \\
\hline KPIG & 7.257 .396 .666 .600 & 105.067 .905 .142 \\
\hline MAPB & 105.094 & -148.469 \\
\hline MINA & 59.589 .279 .944 & -41.505 .560 .773 \\
\hline NASA & -7.816 .878 .244 & -3.553 .213 .367 \\
\hline PANR & -1.290 .744 & -100.015 .304 \\
\hline PDES & 8.677 .102 .985 & -73.830 .687 .583 \\
\hline PGLI & 12.819 & 614.729 \\
\hline PJAA & 157.129 .941 .239 & -252.588 .416 .872 \\
\hline PNSE & -12.702 .140 .359 & -37.504 .285 .527 \\
\hline PSKT & -10.256 .166 .165 & -15.358 .870 .098 \\
\hline PTSP & 20.900 .575 & -59.028557 \\
\hline PUDP & -514.028 .087 & -16.335077024 \\
\hline PZZA & 159.641 .540 .776 & -8.233 .470 .530 \\
\hline SHID & -10.732 .275 .108 & -28.509 .759 .474 \\
\hline Sumber: www.idx.co.id &
\end{tabular}

Salah satu perusahaan sektor pariwisata PT rusahaan merupakan salah satu yang dilakukan Jakarta International Hotel \& Development Tbk, manajemen untuk memenuhi kewajibannya ter(JIHD) mencatat penurunan laba usaha sebesar hadap para pemilik perusahaan dan untuk menRp. 224.24 miliar atau 235\% pada tahun 2020 da- capai tujuan perusahaan. (Ardimas, Ekonomi, \& ri laba usaha tahun 2019 yang mencapai Rp.95.33 Gunadarma, 2014). Penilaian kinerja keuangan miliar. Perusahaan lainnya PT Bayu Buana Tbk dapat dipakai sebagai alat pengambilan keputusan. (BAYU), akibat terjadinya pandemi Covid-19 di seSektor pariwisata merupakan salah satu mester pertama tahun 2020, perusahaan men- sektor yang terkena dampak paling parah dari tercatat penurunan pendapatan hingga 60,91\% year jadinya pandemi Covid-19. Ketua Umum Asosiaon year (yoy) menjadi Rp 408,82 miliar dan me- si Pengusaha Indonesia (Apindo) Hariyadi Sungalami rugi bersih Rp 7,04 miliar. Penurunan laba kamdani menyebutkan lebih dari 2.000 hotel usaha mempengaruhi kinerja keuangan peru- dan 8.000 restoran ditutup. (Gunawan, 2020). sahaan.

Perusahaan yang bergerak pada sektor hotel, res-

Kinerja keuangan adalah gambaran kondisi toran dan pariwisata akan menghadapi beberapa keuangan perusahaan yang dianalisis dengan risiko antara lain menurunnya pendapatan dan meng-gunakan alat-alat analisis keuangan laba usaha, penurunan ini tentunya akan memsehingga dapat diketahui kekurangan dan prestasi pengaruhi kinerja keuangan perusahaan. Pandemi yang dicapai perusahaan dalam satu periode Covid-19 membuat sektor pariwisata menjadi titertentu. Kinerja keuangan melihat pada laporan dak staibil untuk itu perlu dilakukan penelitian keuangan perusahaan, informasi dalam laporan analsiis dampak pandemi Covid-19 terhadap kikeuangan sangat penting untuk dapat mengetahui nerja keuangan perusahaan sub sektor hotel, resposisi keuangan perusahaan. (Hanafi, Mamduh M; toran dan pariwisata, dengan melakukan analisis Halim, 2012). Analisis kinerja keuangan suatu pe- terhadap laporan keuangan, dapat mengetahui 
apakah terdapat perbedaan kinerja keuangan sebelum dan sesudah diumumkannya kasus Covid19 pertama kali di Indonesia. Analisis kinerja keuangan menggunakan rasio likuiditas, rasio solvabilitas, rasio profitabilitas dan rasio pasar. Rasio Likuiditas (Liquidity Ratio) merupakan rasio yang mengukur kemampuan perusahaan untuk menyelesaikan kewajiban/hutang jangka pendeknya. Adapun yang termasuk dalam rasio ini antara lain current ratio (rasio lancar) dan cash ratio (rasio kas) (Maith, 2013).

Rasio Solvabilitas (Leverage Ratio) adalah rasio yang digunakan untuk menilai kemampuan perusahaan untuk membayar semua utang utangnya. (Dewi, 2016). Rasio Profitabilitas merupakan rasio yang digunakan untuk mengukur kemampuan perusahaan dalam mencapai keuntungan. Rasio profitabilitas ini merupakan hasil akhir dari keputusan dan kebujakan yang dibuat perusahaan, dengan rasio ini dapat mengukur efektifitas manajemen perusahaan dalam menggunakan asset maupun modalnya untuk menghasilkan keuntungan (Pitoyo \& Lestari, 2018).

Rasio Pasar yaitu rasio yang digunakan di pasar modal, rasio ini berhubungan dengan harga saham perusahaan, serta nilai buku perusahaan. Rasio pasar menjadi ukuran investor dalam melihat prospek perusahaan di masa yang akan datang dan risiko dari suatu keputusan investasi. Rasio ini meggambarkan kondisi pasar saham pada periode tertentu. Rasio Pasar bermanfaat bukan hanya untuk internal perusahaan tetapi juga eksternal perusahaan (Hanafi, Mamduh M; Halim, 2012).

\section{Hipotesis Penelitian}

"Terdapat perbedaan kinerja keuangan perusahaan sub sektor hotel, restoran dan pariwisata sebelum dan sesudah diumumkannya kasus pandemi Covid-19 di Indonesia."

\section{METODE PENELITIAN}

Jenis penelitian yang digunakan adalah penelitian kuantitatif dengan pendekatan deskriptif. Data yang digunakan adalah data sekunder yaitu data Laporan keuangan perusahaan. Populasi penelitian adalah 35 keseluruhan perusahaan sektor hotel, restoran dan pariwisata yang terdaftar di Bursa Efek Indonesia. Teknik pengambilan sampel dilakukan teknik purposive sampling dan diperoleh sebanyak 30 perusahaan sampel. Kriteria sampel adalah (1) Perusahaan sektor hotel, restoran dan pariwisata yang terdaftar di Bursa Efek Indonesia sampai tahun 2020 ; (2) Tersedia laporan keuangan selama periode triwulan III Tahun 2019 dan 2020.

Penelitian ini menggunakan paired sample ttest, yang digunakan sebagai uji komparatif atau perbedaan apabila skala data kedua variabel merupakan data kuantitatif (interval atau rasi) (Nugeraha, Mandra, \& Ardana Putra, 2016). Pengujian ini digunakan untuk menganalisa keefektifan perlakuan, yang ditandai sebelum dan rata-rata sesudah diberikan perlakuan sehingga dapat diketahui seberapa besar perbedaan kinerja keuangan perusahaan sektor hotel, restoran dan pariwisata di Indonesia, Variabel-variabel pada penelitian ini, yang digunakan adalah :

1) Data sebelum kasus pandemi Covid-19 diumumkan secara nasional di Indonesia untuk pertama kali yang digunakan yaitu laporan ke- 
uangan triwulan ke 3 tahun 2019 yang meliputi data laporan keuangan berupa rasio likuiditas yang diukur dengan current ratio (CR), rasio solvabiltas dengan menggunakan debt to equity ratio (DER), rasio profitabiltas diukur dengan rasio return on equity ratio (ROE) dan rasio pasar menggunakan price earning ratio (PER).

2) Data sesudah kasus pandemi Covid-19 diumumkan secara nasional di Indonesia untuk petama kali yang digunakan yaitu laporan keuangan triwulan ke 3 tahun 2020 (Ilhami \& Thamrin, 2021).
3) Pengumuman terjadinya kasus pandemi Covid -19 pertama kali di Indonesia diumumkan tanggal 2 Maret 2020.

Pengujian statistik dilakukan dengan menguji kinerja keuangan sebelum dan sesudah pengumuman pandemi Covid-19 pertama kali di Indonesia. Tahap-tahap pengujian menggunakan pengujian parsial untuk variabel penelitian dengan Paired Samples T Test. Tingkat signifikansi atau nilai alfa pada penelitian ini ditetapkan adalah sebesar 0,05 atau $5 \%$.

\section{HASIL DAN PEMBAHASAN}

Tabel 2 Paired Samples Statistics

\begin{tabular}{crrrr}
\hline & \multicolumn{1}{c}{ Mean } & N & Std. Deviation & Std. Error Mean \\
\hline CR sebelum & 187.3000 & 30 & 102.46114 & 18.70676 \\
\hline CR sesudah & 225.9000 & 30 & 173.02548 & 31.58999 \\
\hline DECR sebelum & 93.5000 & 30 & 66.95225 & 12.22375 \\
\hline DER sesudah & 125.2667 & 30 & 86.55631 & 15.80295 \\
\hline ROE sebelum & 10.6333 & 30 & 8.64823 & 1.57894 \\
\hline ROE sesudah & -19.1000 & 30 & 28.67698 & 5.23568 \\
\hline PER sebelum & 16.0790 & 30 & 31.36373 & 5.72621 \\
\hline PER sesudah & -6.1207 & 30 & 41.07355 & 7.49897 \\
\hline
\end{tabular}

Berdarkan tabel dua, rata-rata current ratio (rasio lancar) sesudah terjadinya pandemi Covid19 mengalami peningkatan dan masih berada di antara 100-200\% artinya perusahaan sektor hotel, an retoran dan pariwisata masih dalam kondisi likuid dan memiliki kemampuan untuk membayar kewajiban jangka pendek yang jatuh tempo.

Rata-rata rasio debt equity to ratio (DER) sebelum pandemi Covid-19 memiliki nilai rata- saat sebelum pandemi Covid-19 memiliki nilai rata 93,36\% dan sesudah pandemi meningkat 10,63 dan sesudah pandemi rata-rata rasio ini memenjadi 125,05\%, meningkatnya rasio ini menun- nurun 19,1 artinya kemampuan perusahaan hotel, jukkan menurunnya kemampuan perusahaan un- restoran dan pariwisata dalam mendapatkan ketuk mendapatkan tambahan dana dari kreditur untungan dengan modal sendiri mengalami penukarena adanya risiko yang akan ditanggung kre- runan yang cukup signifikan. Penurunan ini terjadi 
karena menurunnya jumlah laba dan adanya kerugian di masa pandemi Covid-19.

Nilai rata-rata price earning rasio (PER) se- menunjukkan harapan yang baik terhadap perbelum pengumuman kasus pandemi Covid-19 tumbuhan perusahaan. (Napitupulu, 2017). Bagi 16.07\% mengalami penurunan 6.12\%. Rasio PER Investor semakin tinggi rasio PER maka laba yang mengukur prospek perusahaan di mata investor. diharapkan juga meningkat.

Rasio ini terlihat pada harga saham yang bersedia

\section{Pengujian Hipotesis}

Tabel 3 Paired Samples Test

\begin{tabular}{lcccr}
\hline & & t & df & Sig. (2-tailed) \\
\hline Pair 1 & CR sebelum - CR sesudah & -1.762 & 29 & .089 \\
\hline Pair 2 & DER sebelum - DER sesudah & -5.416 & 29 & .000 \\
\hline Pair 3 & ROE sebelum - ROE sesudah & 5.370 & 29 & .000 \\
\hline Pair 4 & PER sebelum- PER sesudah & 2.114 & 29 & .043 \\
\hline
\end{tabular}

Dari tabel tiga, hasil uji beda paired sam- ber daya yang ada dalam perusahaan untuk mengpel $t$ test tidak terdapat perbedaan kinerja keu- hasilkan laba, ketidakmampuan ini juga dipengaangan yang diukur dengan current ratio (rasio ruhi oleh faktor eksternal yaitu terjadinya pandelancar) karena nilai signifikansi 0,089 lebih besar mi Covid-19.

dari 0.05 , Tidak adanya perbedaan rasio lancar mengindikasikan pengelolaan aset lancar dan hutang lancar perusahaan hotel, restoran dan pariwisata masih dalam kondisi stabil.

Berdasarkan uji beda paired sampel $t$ test Debt to Equity ratio (DER) nilai signifikansi 0,000 lebih kecil dari alpha 0,05 sehingga terdapat perbedaan rasio DER sebelum dan sesudah terjadinya pandemi Covid-19 artinya meningkatnya sumber pendanaan hutang pada perusahaan hotel, restoran dan pariwisata setelah terjadinya pandemi Covid-19 di Indonesia.

Rasio Return On Equity (ROE) dari nilai signifikansi menunjukkan ada perbedaan kinerja keuangan pada perusahaan hotel, restoran dan pariwisata. Akibat pandemi Covid-19, sektor jasa ini mengalami penurunan dalam menghasilkan pendapatan. Penurunan ROE menunjukkan menurunnya kinerja manajemen dalam mengelola sum-
Hasil pada tabel tiga menunjukkan bahwa variabel price earning ratio (PER) pada perusahaan hotel, restoran dan pariwisata di Indonesia terkena dampak pandemi Covid-19 tapi tidak signifikan, hal ini berarti investor di pasar modal Indonesia masih optimis terhadap pertumbuhan sektor pariwisata di Indonesia. Langkah strategis pemerintah dalam memulihkan sektor pariwisata memberikan sentimen positi bagi investor bahwa akan ada perbaikan kinerja pada industri ini.

\section{SIMPULAN}

Berdasarkan hasil olah data data dan uji statistik yang telah dilakukan, maka dapat di-simpulkan secara keseluruhan terjadinya pandemi Covid-19 di Indonesia memberi dampak pada sektor hotel, restoran dan pariwisata, namun tidak terdapat perbedaan yang signifikan Current Ratio dan Price eraning ratio antara sebelum dan 
sesudah terjadinya pandemi Covid -19 di Indonesia, Pada Debt equity to ratio dan ratio Return on equity terdapat perbedaan yang signifikan sebelum dan sesudah terjadinya pandemi Covid-19 di Indonesia. Sektor hotel restoran dan pariwisata perlu melakukan inovasi dan promosi, pemerintah dan pengusaha pada sektor ini bekerjasama mengambil langkah strategis dan konsisten untuk meningkatkan kinerja industri hotel, restoran dan pariwisata Indonesia.

\section{DAFTAR PUSTAKA}

Ardimas, W., Ekonomi, F., \& Gunadarma, U. (2014). Pengaruh kinerja keuangan dan corporate social responsibility terhadap nilai perusahaan pada bank. Benefit Jurnal Manajemen Dan Bisnis.https://doi.org/10.14414/jbb.v5i2.547

Dewi, P. E. D. M. (2016). Pengaruh Rasio Likuiditas, Rasio Profitabilitas, Rasio Aktivitas, Rasio Solvabilitas, Dan Rasio Nilai Pasar Terhadap Return Saham. Jurnal Ilmiah Akuntansi.

Gunawan, R. A. (2020). Hubungan Antara Pandemi Covid-19 dan harga saham Perusahaan Sub Sektor Hotel, Restoran Dan Pariwisata Yang Terdaftar Di BEI. Journal Prosiding Working Papers Series In Management, 12(2), 55-70.

Hanafi, Mamduh M; Halim, A. (2018). Analisis Laporan Keuangan, Edisi Kelima. Yogyakarta: UPP STIM YKPN.

Ilhami, \& Thamrin, H. (2021). Analisis Dampak Covid 19 Terhadap Kinerja Keuangan Perbankan Syariah Di Indonesia. Jurnal Tabarru': Islamic Banking and Finance, 4(1), 37-45. https://doi.org/10.25299/jtb.2021.vol4(1).6068

Kurniasih, S., \& Surachim, A. (2019). Debt to Equity Ratio (DER) dan Return On Asset (ROA) untuk Meningkatkan Harga Saham. Strategic: Jurnal Pendidikan Manajemen Bisnis, 18(2), 44. https://doi.org/10.17509/strategic.v18i2.17590

LPEM-FEB-UI. (2020). Dampak Pandemi Covid-19 terhadap Pariwisata Indonesia: Tantangan , Outlook dan Respon Kebijakan. Pusat Kajian Iklim Usaha Dan GVC - LPEM FEB UI, (April). Retrieved from https://www.lpem.org/wpcontent/uploads/2020/04/Briefing-NoteDampak-Pandemi-Covid-19-terhadap-Pariwisata-
LPEM-UI-April-2020.pdf

Maith, H. A. (2013). Analisis Laporan Keuangan dalam mengukur kinerja keuangan pada PT Hanjaya Mandala Sampoerna Tbk. Jurnal Riset Ekonomi, Manajemen, Bisnis Dan Akuntansi. https://doi.org/10.35794/emba.v1i3.2130

Napitupulu, M. A. (2017). Faktor-Faktor Yang Mempengaruhi Price Earning Ratio (PER) Pada Perusahaan Sektor Perkebunan Yang Terdaftar di Bursa Efek Indonesia Periode 2011-2014. Jurnal Akuntansi Dan Keuangan Methodist, 1(9), 57-68.

Nidya Afrinda. (2013). Analisis Pengaruh Likuiditas Dan Solvabilitas Terhadap Profitabilitas Pda Perusahaan Makanan Dan Minuman Yang Terdaftar Di BEI. Jurnal Fakultas Ekonomi.

Nugeraha, A., Mandra, I. G., \& Ardana Putra, I. N. N. (2016). Analisis Perbandingan Kinerja Keuangan Sebelum Dan Sesudah Diberlakukannya Tax Amnesty Periode Pertama Pada Perusahaan Sub Sektor Property Dan Real Estate Yang Terdaftar Di Bei. Distribusi - Journal of Management and Business, 4(1), 1-19. https://doi.org/10.29303/jdm.v4i1.8

Pitoyo, M. M., \& Lestari, H. S. (2018). Pengaruh Likuiditas Terhadap Profitabilitas Perusahaan Manufaktur yang Terdaftar di Bursa Efek Indonesia. Jurnal Manajemen Bisnis.

Rahma, A. A. (2020). Potensi Sumber Daya Alam dalam Mengembangkan Sektor Pariwisata Di Indonesia. Jurnal Nasional Pariwisata, 12(1), 1. https://doi.org/10.22146/jnp.52178

Siswantoro. (2020). Efek diumumkannya kasus pertama Covid-19 terhadap harga saham dan total saham yang diperdagangkan ( The effect of the first Covid-19 case announcement on stock prices and stock trading totals ). Jurnal Akuntansi, Keuangan, Dan Manajemen (Jakman), 1(3), 227$238 . \quad$ Retrieved from https://doi.org/10.35912/jakman.v1i3.38

Sugihamretha, I. D. G. (2020). Respon Kebijakan: Mitigasi Dampak Wabah Covid-19 Pada Sektor Pariwisata. Jurnal Perencanaan Pembangunan: The Indonesian Journal of Development Planning, 4(2), 191-206 https://doi.org/10.36574/jpp.v4i2.113

Utami, B. S. A., \& Kafabih, A. (2020). Sektor Pariwisata Indonesia di Tengah Pandemi Covid 19. Jurnal Dinamika Ekonomi Pembangunan (JDEP), 4(1), 368-375. Retrieved from http://jdep.upnjatim.ac.id/index.php/jdep/articl e/view/121 